\title{
Potential Slow Release Fertilizers and Acid Soil Conditioners Obtained by One-Pot Mechanochemical Activation of Chrysotile:Cement Roofing Sheets with $\mathrm{K}_{2} \mathrm{HPO}_{4}$
}

\author{
Roger Borges ${ }^{a}$ and Fernando Wypych ${ }^{\oplus *}, a$ \\ ${ }^{a}$ Departamento de Química, Universidade Federal do Paraná, CP 19032, \\ 81531-980 Curitiba-PR, Brazil
}

\begin{abstract}
Chrysotile:cement roofing sheets were milled with and without $\mathrm{K}_{2} \mathrm{HPO}_{4}$. As indicated by $\mathrm{X}$-ray diffraction (XRD), the samples crystallinities were reduced with the increasing milling time. The same tendency was observed by scanning electron microscopy (SEM) and transmission electron microscopy (TEM), with disaggregation of the chrysotile fiber bundles and formation of non-fibrous micrometric agglomerate particles. After milling for $16 \mathrm{~min}$, most of the phases present in the cement and chrysotile were transformed into amorphous materials, except quartz, in which the structure integrity was preserved, and calcium carbonate, where the particles were reduced to nanometric size. Both milled samples were submitted to release experiments in water, where the characteristics of a potential slow release fertilizer and acid soil conditioner were observed. The process is a viable alternative not only to eliminate the hazard of chrysotile fibers without the need to remove them from the cement matrix, but also as aggregation value to the milled almost amorphous mixture.
\end{abstract}

Keywords: chrysotile, cement roofing sheets, mechanochemical activation, slow release fertilizer

\section{Introduction}

Asbestos containing materials (ACM) indicate materials containing minerals from the serpentine groups, like chrysotile or white asbestos $\left(\mathrm{Mg}_{3} \mathrm{Si}_{2} \mathrm{O}_{5}(\mathrm{OH})_{4}\right)$ and/or amphibole minerals like actinolite $\left(\mathrm{Ca}_{2}\left(\mathrm{Mg}, \mathrm{Fe}^{\mathrm{II}}\right)_{5} \mathrm{Si}_{8} \mathrm{O}_{22}(\mathrm{OH})_{2}\right)$, amosite or brown asbestos $\left((\mathrm{Fe}, \mathrm{Mg})_{7}\left(\mathrm{Si}_{4} \mathrm{O}_{11}(\mathrm{OH})\right)_{2}\right)$, anthophyllite $\left(\mathrm{Mg}_{7}\left(\mathrm{Si}_{8} \mathrm{O}_{22}\right)(\mathrm{OH})_{2}\right)$ and crocidolite, also known as blue asbestos $\left(\mathrm{Na}_{2} \mathrm{Fe}_{5}\left[\mathrm{Si}_{4} \mathrm{O}_{11}(\mathrm{OH})\right]_{2}\right) .{ }^{1}$ In spite of being banned in many countries due to health hazards, ACM can still be present in many products and building materials like floor tiles, roofing sheets, tiles and wall boards, which must be safely discarded or destroyed after removal. Due to the lower toxicity of white asbestos, in many countries chrysotile is still permitted, excluding Brazil, where the use was banned by the Supreme Court in September 2017. This is the reason why most studies of the inertization conducted with ACM use chrysotile, for example, but the results can be also extrapolated to other asbestiform minerals.

Chrysotile is a fibrous hydrated magnesium silicate whose structure is formed by octahedral brucite-like $\left(\mathrm{Mg}(\mathrm{OH})_{2}\right)$ sheets covalently bonded to silicon-centered

*e-mail: wypych@ufpr.br tetrahedral sheets, forming rolled papyrus-like nanoscrolls, which are packed in bundles in the macroscopic fibers. ${ }^{2-4}$ The main damaging effect of asbestos to the human body is caused by isolated fibers or fibrils, which can be inhaled and allocated in the lungs, causing respiratory problems such as lung cancers. ${ }^{3,5-7}$ These fibers are not destroyed by the action of any natural agent in the soil or the body, so ecological methods to detoxify these fibers are welcome from an environmental standpoint. In this context, inertization of this class of materials and transforming them into new products is obviously preferred in comparison with the landfill disposal, where the minerals will only accumulate and continue to be a potential source of human health hazards.

Brazil is one of the largest producers and exporters of chrysotile in the world. In Brazil, chrysotile was used to prepare asbestos cement for the manufacture of corrugated roof sheets, water tanks, brake linings and pads, among others. Considering the number of products that contain chrysotile asbestos as raw material, it is important to dispose of these products safely after their use or reuse.

In this context, studies of ecological treatments to detoxify asbestos/cement materials, whether in the form of patents or scientific articles, are in line with the global 
trend for reuse of industrial wastes, transforming them into new value-added products.

Many methods to destroy or detoxify asbestos are reported using different approaches. ${ }^{8-18}$ In this respect, mechanochemical activation has been successfully used. It involves grinding of particles and subjecting them to chemical reactions like dehydroxylation, which is a solvent free method and is usually more environmentally friendly than treating wastes containing asbestos, including chrysotile, by conventional means, such as thermal or acid treatments. ${ }^{19-23}$

The main purpose of this paper is to investigate the mechanochemical treatment to detoxify chrysotile asbestos from chrysotile:cement roofing sheets (CCRS), considering also treatments in the presence of $\mathrm{K}_{2} \mathrm{HPO}_{4}$, transforming this harmful waste into an amorphous material with slow release characteristics that can be potentially used as acid soil conditioner and fertilizer. The vibration disk mill used provides promising results with reduced time of milling compared with other mills, for example high-energy ball mill. After experimental essays, powder X-ray diffraction (XRD), scanning electron microscopy (SEM), transmission electron microscopy (TEM) and Brunauer-Emmet-Teller (BET) analyses were performed to verify the destruction of chrysotile structure. The potential as acid soil conditioner as well as slow release fertilizer was determined in deionized water as a control, and in acetic acid solution trying to simulate the acid soil conditions.

\section{Experimental}

$\mathrm{K}_{2} \mathrm{HPO}_{4}$ was purchased from Neon Comercial (99\%) and the chrysotile/cement corrugated roofing sheets (Eternit) were acquired from a construction materials store. According to the manufacturer's information, the sheets were fabricated with chrysotile fiber supplied by SAMA S/A - Minerações Associadas and incorporated in a concentration of around $10 \%$ in Portland cement (by mass). As already described, this chrysotile has some contamination from talc $\left(\mathrm{Mg}_{3} \mathrm{Si}_{4} \mathrm{O}_{10}(\mathrm{OH})_{2}\right)$ and traces of iron oxides/hydroxides (goethite, hematite and magnetite)..$^{16,24}$

Two sets of samples were prepared, in the first $15.012 \mathrm{~g}$ of raw CCRS material and in the second, $15.030 \mathrm{~g}$ of CCRS in the presence of $1.102 \mathrm{~g}$ of $\mathrm{K}_{2} \mathrm{HPO}_{4}$ (molar ratio chrysotile: $\mathrm{K}_{2} \mathrm{HPO}_{4}$ of approximately $1: 2$ ). ${ }^{25}$ Although $\mathrm{K}_{2} \mathrm{HPO}_{4}$ has been used in all experiments because of its availability, any potassium phosphate phase like $\mathrm{K}_{2} \mathrm{HPO}_{4}$ or $\mathrm{K}_{3} \mathrm{PO}_{4}$ could also be milled, resulting in similar materials. The samples were placed in tungsten carbide grinding vessels with volume of $250 \mathrm{~mL}$, the pneumatic clamping device was closed and the mixture was milled at $1420 \mathrm{rpm}$ in a Herzog HSM 100P vibration disk mill.

The samples of raw CCRS were milled for 1, 2, 4, 8, 12 and 16 min and the mixture of raw CCRS/ $\mathrm{K}_{2} \mathrm{HPO}_{4}$ was only milled for $16 \mathrm{~min}$. The samples were respectively denominated as CCRS (raw sample); CCRS-x min for the samples milled for $\mathrm{x}$ min and CCRS/ $\mathrm{K}_{2} \mathrm{HPO}_{4}-16 \mathrm{~min}$, for the mixture CCRS $/ \mathrm{K}_{2} \mathrm{HPO}_{4}$ milled for $16 \mathrm{~min}$.

XRD measurements were performed using a Shimadzu XRD-6000 diffractometer, with $\mathrm{CuK} \alpha$ radiation source of $\lambda=1.5418 \AA$, current of $30 \mathrm{~mA}$ and tension of $40 \mathrm{kV}$. The samples were placed on glass sample holders and the XRD patterns were acquired using the $\theta / 2 \theta$ Bragg-Brentano geometry, with a dwell time of $2^{\circ} \mathrm{min}^{-1}$, step of $0.02^{\circ}$ and $2 \theta$ range from 3 to $40^{\circ}$.

The SEM images were obtained using a Cambridge Scan 360 SEM operating at $1 \mathrm{kV}$ and a Zeiss Supra 55 FEG-VP operating at $3 \mathrm{keV}$. For these observations, the samples were mounted on conductive carbon adhesive tabs and submitted to gold sputtering. TEM and selected area electron diffraction (SAED) measurements were performed by depositing the sample material on a $3 \mathrm{~mm}$ formvar coated copper grid and examining them with a JEOL JEM EX-II microscope, at $80 \mathrm{kV}$. Gold was used as internal standard for indexation of the SAED patterns.

The evaluation of the samples' behavior according to different $\mathrm{pH}$ values was performed in an aqueous acetic acid solution, simulating acid soil conditions, and also with deionized water, as control experiments. Briefly, $100 \mathrm{mg}$ of each sample were added to $100 \mathrm{~mL}$ of deionized water or an aqueous acetic acid solution and the $\mathrm{pH}$ changes were controlled, and the contents of the released elements were determined after $30 \mathrm{~min}$. To quantify the nutrient release, the inductively coupled plasma-optical emission spectrometry (ICP OES) technique was used. The spectrometric determinations were carried out in a Thermo Scientific simultaneous axial view ICP OES spectrometer (model iCAP 6500) and the Thermo Scientific iTEVA (version 1.2.0.30) program was used for data treatment. The operating conditions are shown in Table 1. Argon gas was supplied by White Martins, with purity of $99.998 \%$, and was previously purified in an appropriate filter system. A reference stock solution containing $1000 \mathrm{mg} \mathrm{L}^{-1}$ of $\mathrm{P}$ (Specsol) and also another reference solution containing $1000 \mathrm{mg} \mathrm{L}^{-1}$ of the analytes $\mathrm{K}$ and $\mathrm{Mg}$ (AccuStandard) were used to compose the multi-elemental standard solutions used for calibration, in the concentration range from 0.01 to $2.0 \mathrm{mg} \mathrm{L}^{-1}$ of analytes in $1.0 \% \mathrm{v} / \mathrm{v} \mathrm{HNO}_{3}$.

The determination of the textural properties of the raw CCRS and milled samples for 16 min (CCRS-16 min 
Table 1. Characteristics and operating conditions used for analysis by ICP OES

\begin{tabular}{lc}
\hline Parameter & Characteristic \\
\hline Radiofrequency / MHz & 40 \\
Radiofrequency power / W & 1150 \\
Plasma gas flow / $\left(\mathrm{L} \mathrm{min}^{-1}\right)$ & 12.0 \\
Auxiliary gas flow / $\left(\mathrm{L} \mathrm{min}^{-1}\right)$ & 1.0 \\
Gas flow in the nebulizer / $\left(\mathrm{L} \mathrm{min}^{-1}\right)$ & 0.7 \\
Torch & quartz for axial view \\
Nebulizer & concentric \\
No. of replicates & 3 \\
Analytical lines / nm & $\mathrm{K}$ (I): $766.490 ;$ \\
& $\mathrm{Mg}$ (II): $280.270 ;$ \\
& $\mathrm{P}$ (I): $213.618 ;$ \\
\end{tabular}

I: atomic line; II: ionic line.

and $\mathrm{CCRS} / \mathrm{K}_{2} \mathrm{HPO}_{4}-16 \mathrm{~min}$ ) was carried out by using a Quantachrome gas sorption analyzer, model NOVA 2000e.

The samples were degassed under vacuum at $120^{\circ} \mathrm{C}$ for $2 \mathrm{~h}$ and the analyses were carried out in liquid $\mathrm{N}_{2}\left(-196^{\circ} \mathrm{C}\right)$. The specific surface areas were calculated using the multipoint BET method by the adsorption isotherm in the range of relative pressures from $0.05-0.30$. Pore diameter and the pore volume were calculated using the desorption isotherm or Barrett-Joyner-Halenda (BJH) method, also from the desorption isotherm. The surface areas were obtained by the t-plot method from the adsorption isotherm.

\section{Results and Discussion}

The XRD patterns of the raw CCRS (Figure 1c) showed that it is composed mainly of chrysotile (Figure 1b), quartz $\left(\mathrm{Q} ; \mathrm{SiO}_{2}\right)$ and calcite $\left(\mathrm{Ca} ; \mathrm{CaCO}_{3}\right){ }^{26}$ In the materials obtained from the tests involving the milling of CCRS, the diffraction peaks reduce the intensity of chrysotile and calcite progressively with the increasing milling time.

After 16 min of milling, only broad diffraction peaks of quartz and a low intensity and broad peak of $\mathrm{CaCO}_{3}$ could be identified, indicating the sample amorphization and reduction of particles size. Quartz is resistant to milling as already described for other systems. ${ }^{19,25,27,28}$ In the case of CCRS/ $\mathrm{K}_{2} \mathrm{HPO}_{4}-16$ min (Figure $1 \mathrm{j}$ ), only low intensity peaks of quartz and calcium carbonate could be detected, indicating that $\mathrm{K}_{2} \mathrm{HPO}_{4}$ has an positive effect in the mixture amorphization, as already reported for chrysotile itself. ${ }^{29}$

Figure 2 presents the results obtained by the reduction of the calcite crystalline domains sizes by using the Scherrer equation:

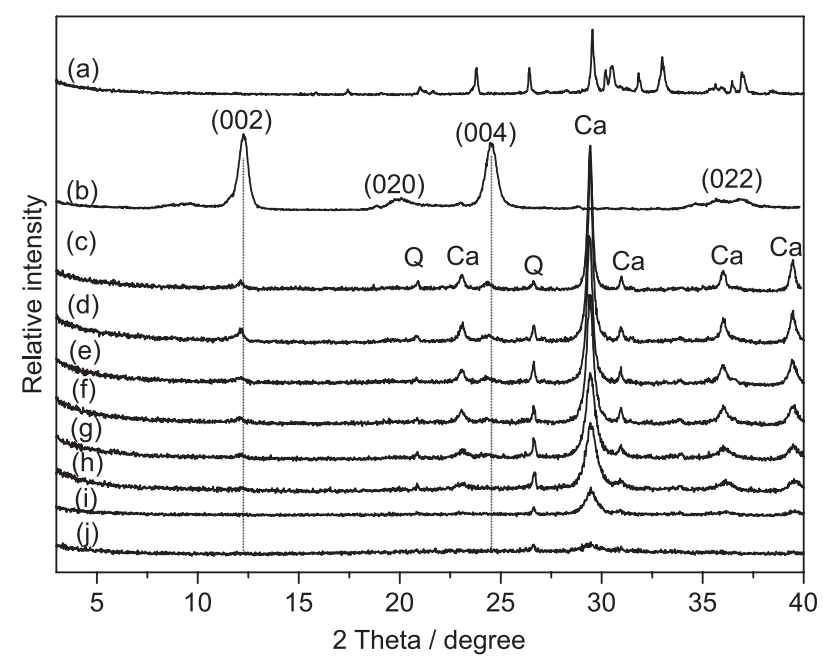

Figure 1. XRD patterns of (a) $\mathrm{K}_{2} \mathrm{HPO}_{4}$; (b) chrysotile; (c) CCRS; (d) CCRS-1 min; (e) CCRS-2 min; (f) CCRS-4 min; (g) CCRS-8 min; (h) CCRS-12 min; (i) CCRS-16 min; and (j) CCRS/K $\mathrm{KPO}_{4}-16 \mathrm{~min}$.

$\mathrm{d}_{\text {crystallite }}=(0.9 \lambda) /(\mathrm{B} \times \cos \theta)$

where $\mathrm{d}$ is the diameter of the crystallite (in $\mathrm{nm}$ ), $\lambda$ is the wavelength, $B$ is the line broadening at full width at half maximum, and $\theta$ is the Bragg angle (diffraction peak close to $29^{\circ}$ in $\left.2 \theta\right) .{ }^{30}$

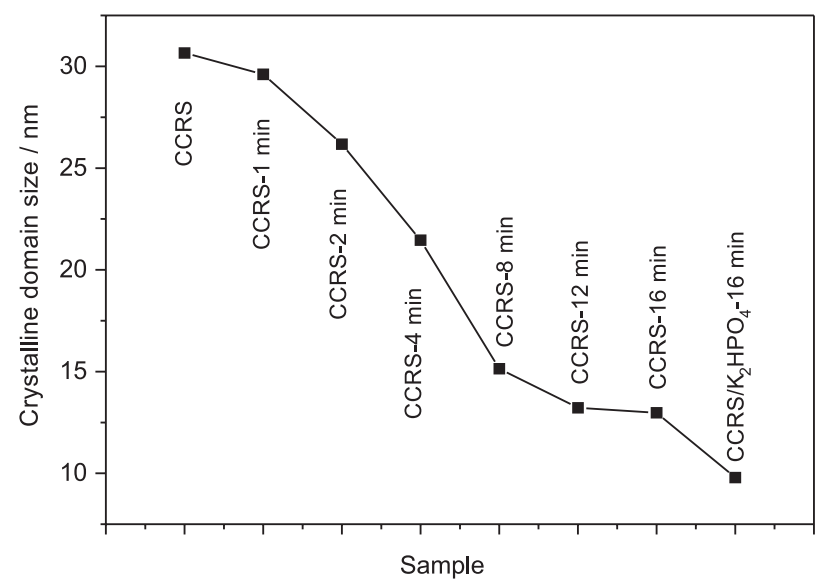

Figure 2. Calcite crystalline domain sizes obtained through the Scherrer equation.

Comparing the results between milled samples and raw CCRS ( $32 \mathrm{~nm}$ ) there is a clear influence of the milling process on crystal size; this effect is even more pronounced in the presence of $\mathrm{K}_{2} \mathrm{HPO}_{4}$, probably because this salt reacts strongly with calcite structure fragments being also consumed in the process.

In the SEM images of the raw CCRS (Figure 3a), a mass of micrometric particles with low aspect ratio and also fiber bundles can be seen, typical of chrysotile morphology. After milling the same CCRS for 4 min (Figure $3 b$ ), the effect of milling can already be observed, with disaggregation of 
the chrysotile fiber bundles and formation of non-fibrous micrometric agglomerate particles mixed with the cement components and the oxides obtained from chrysotile dehydroxylation $\left(\mathrm{SiO}_{2}\right.$ and $\left.\mathrm{MgO}\right)$. After 16 min of milling, the mechanochemical process selectively destroyed the chrysotile structure, since the fibers are no longer observed (Figure 3c), the same as for the milled product obtained from the mixture of CCRS and $\mathrm{K}_{2} \mathrm{HPO}_{4}$ (Figure $3 \mathrm{~d}$ ) after $16 \mathrm{~min}$.

In general, the TEM images (Figure 4) confirm the data from XRD and SEM measurements, where the raw CCRS shows a mixture of chrysotile fibers and a large amount of nanometric particles without apparent ordered morphology in the cement. After milling, the raw CCRS material before (Figure 4c) and after adding $\mathrm{K}_{2} \mathrm{HPO}_{4}$ (Figure 4f) and milling for $16 \mathrm{~min}$, contained only nanometric particles, in accordance with Figure 2.

Figure 5 shows the nitrogen adsorption/desorption isotherm of the raw sample and samples CCRS-16 min and $\mathrm{CCRS} / \mathrm{K}_{2} \mathrm{HPO}_{4}-16 \mathrm{~min}$.

According to the International Union of Pure and Applied Chemistry (IUPAC), the CCRS raw sample isotherms can be classified as type IV, typical of mesoporous absorbents, but after milling process the samples CCRS-16 min and CCRS/K $\mathrm{K}_{2} \mathrm{HPO}_{4}-16$ min present isotherms of type III, typical of nonporous or macroporous solids with strong adsorbent/adsorbent interactions. For more details please consult the IUPAC classification of adsorption/desorption isotherms. ${ }^{31}$

The raw CCRS was gently crushed into small pieces, and as observed in Table 2, presents a specific surface area of $51.1 \mathrm{~m}^{2} \mathrm{~g}^{-1}$, a pore volume of $0.050 \mathrm{~cm}^{3} \mathrm{~g}^{-1}$ and an average pore radius of $20.2 \AA$. As already discussed previously, after milling CCRS in the absence and in the presence of $\mathrm{K}_{2} \mathrm{HPO}_{4}$ for $16 \mathrm{~min}$, the particles sizes are reduced. The specific surface area, the pore volume and the average radius were also reduced to $6.70 \mathrm{~m}^{2} \mathrm{~g}^{-1}, 0.013 \mathrm{~cm}^{3} \mathrm{~g}^{-1}, 19.9 \AA$; and $8.47 \mathrm{~m}^{2} \mathrm{~g}^{-1}, 0.026 \mathrm{~cm}^{3} \mathrm{~g}^{-1}$, and $16.2 \AA$, respectively. Due to the high porosity of the cement and consequent high surface area, the reduction of the textural properties is probably attributed to the adhesion of the nanoparticles transforming in agglomerates and also a change in the structure after the amorphization of the cement components, excluding quartz. It is frequently observed in the literature that the surface area of clay minerals increases and in sequence drops after extensive milling. ${ }^{32}$

The milled samples were found to be mainly composed of carbonates and silicates, originated from the hydrated Portland cement. Those that were almost totally amorphized were added to an aqueous acetic acid solution to simulate their behavior in the presence of acid soils (Table 3), and also to deionized water as control experiments.
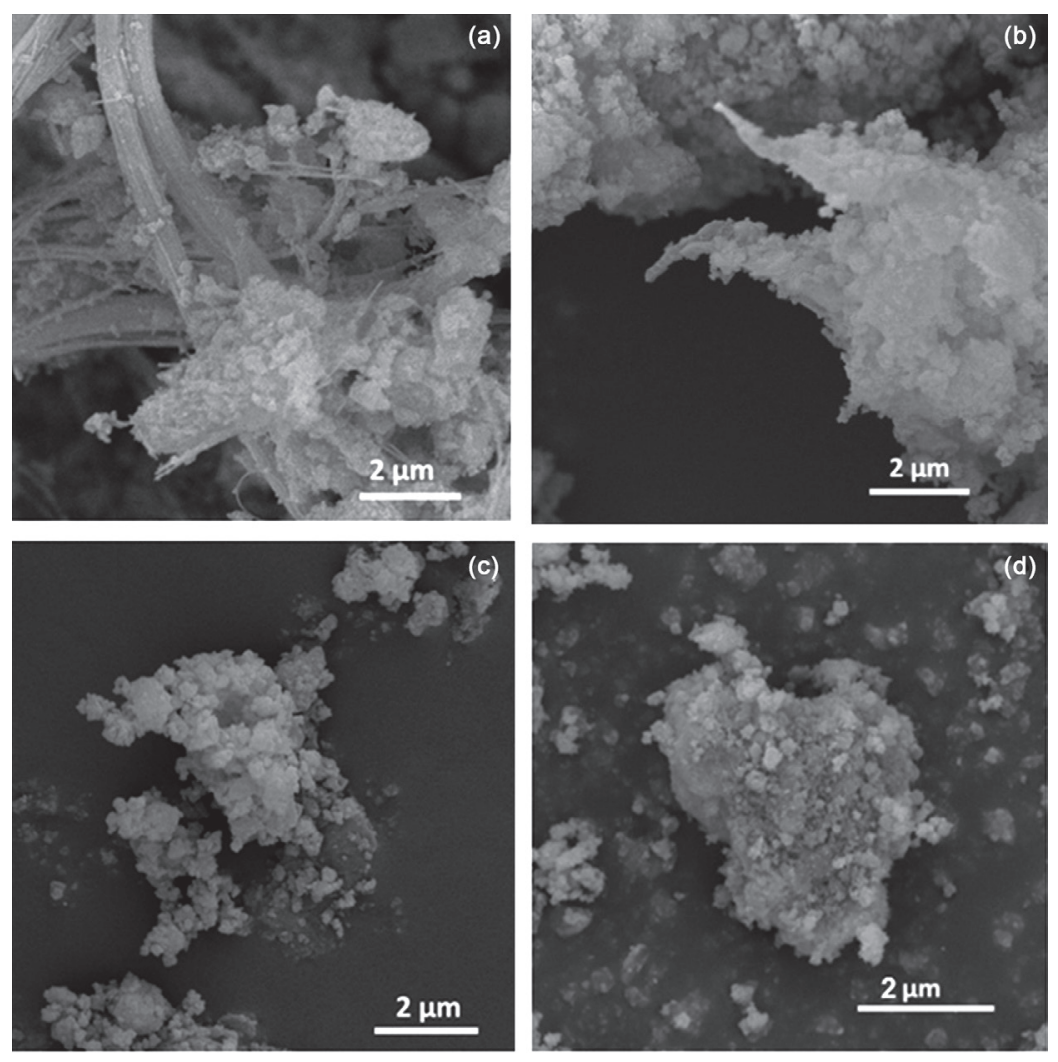

Figure 3. SEM images of (a) the raw CCRS; (b) after milling for $4 \mathrm{~min}$; (c) after milling for $16 \mathrm{~min}$ and (d) $\mathrm{CCRS} / \mathrm{K}_{2} \mathrm{HPO}_{4}$ after milling for 16 min. 

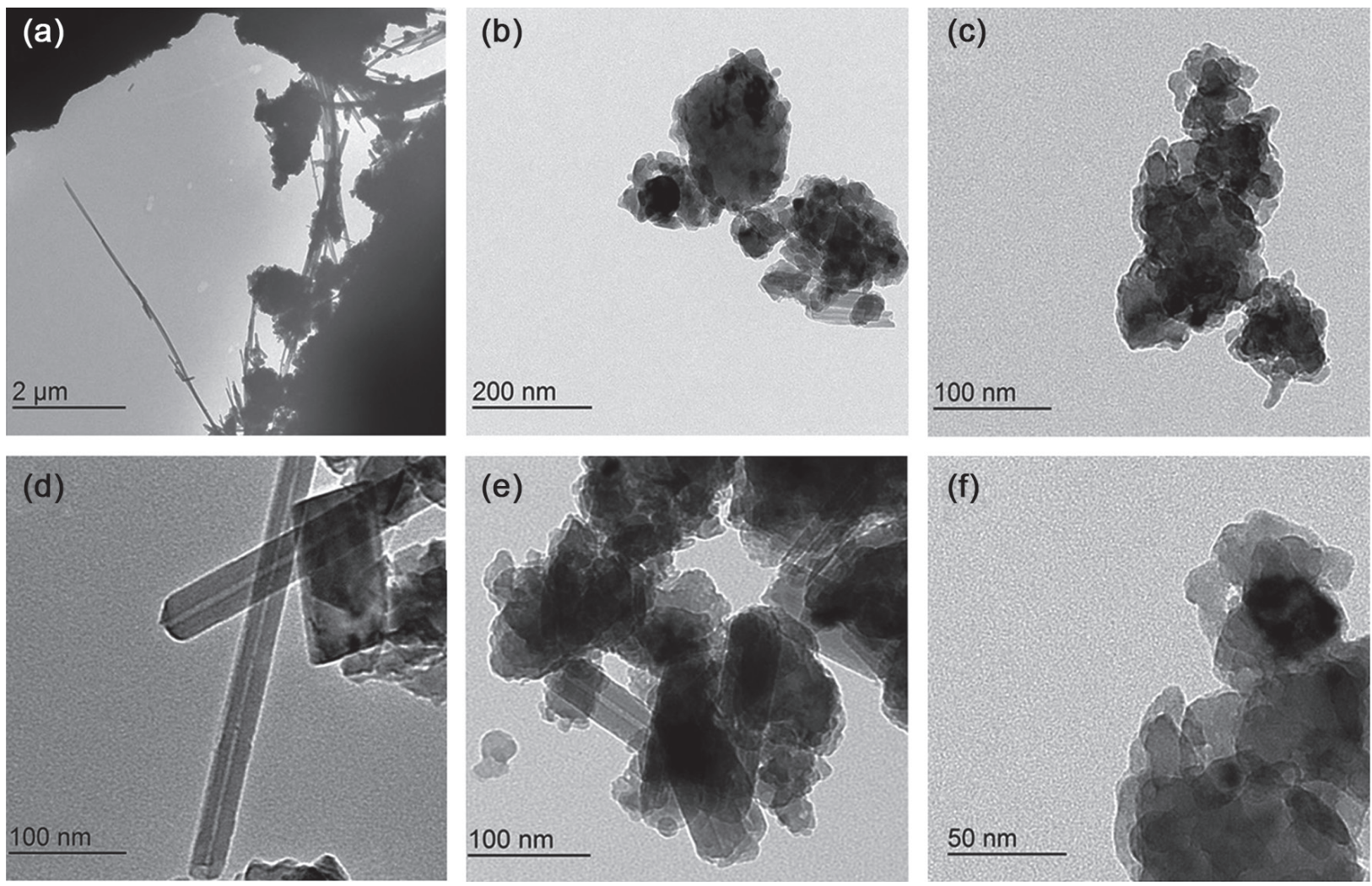

Figure 4. TEM images of (a) the raw CCRS; (b) CCRS-4 min and (c) CCRS-16 min before adding $\mathrm{K}_{2} \mathrm{HPO}_{4}$; and (d) the raw CCRS; (e) CCRS-4 min and (f) CCRS-16 min after adding $\mathrm{K}_{2} \mathrm{HPO}_{4}$.

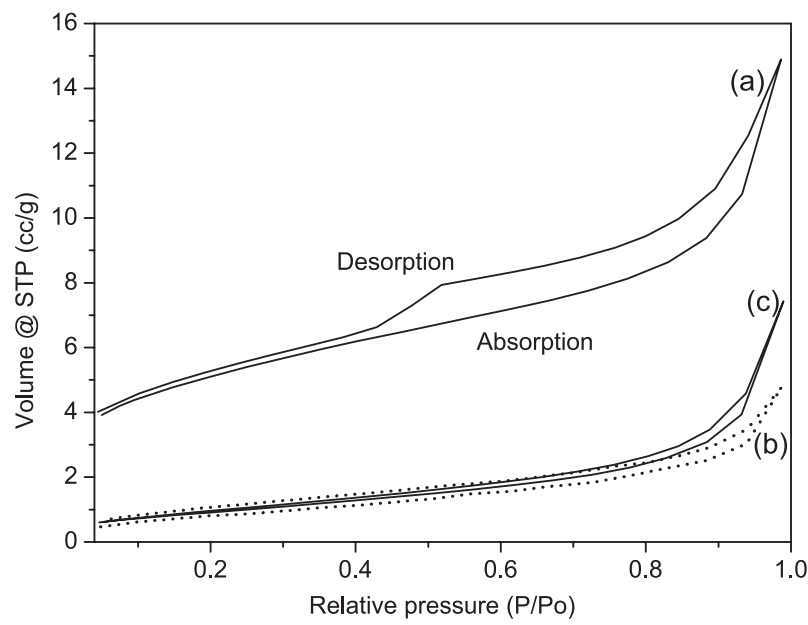

Figure 5. Nitrogen adsorption/desorption isotherm of (a) the raw CCRS sample; and samples (b) CCRS-16 min and (c) CCRS/K $\mathrm{HPO}_{4}-16 \mathrm{~min}$.
As expected, in acidic conditions the nutrients were released in higher percentages than in deionized water, especially $\mathrm{Ca}$ and $\mathrm{Mg}$, since the carbonates present in the milled material are soluble. The release assay results suggested a potential slow release behavior for these materials, since even in acid conditions and after $30 \mathrm{~min}$ in solution the maximum percentage released was $26.52 \%$ for $\mathrm{Ca}$ from the sample CCRS-16 min.

In the assays involving acetic acid solution, the initial $\mathrm{pH}$ was measured as 4.05 and, adding the raw CCRS sample milled for $16 \mathrm{~min}$, the $\mathrm{pH}$ increased to 7.15. The same tendency was observed for the sample CCRS/ $\mathrm{K}_{2} \mathrm{HPO}_{4}$, milled for $16 \mathrm{~min}$, where the $\mathrm{pH}$ increased from 4.05 to 6.62. In this case, the increase of $\mathrm{pH}$ was less pronounced, probably due to the partial consumption of the oxides to produce $\mathrm{Mg}$ and $\mathrm{Ca}$ phosphates, which were released

Table 2. Textural properties of CCRS, CCRS-16 min and CCRS/ $\mathrm{K}_{2} \mathrm{HPO}_{4}-16 \mathrm{~min}$

\begin{tabular}{lccc}
\hline Sample & Surface area $/\left(\mathrm{m}^{2} \mathrm{~g}^{-1}\right)$ & Pore volume / $\left(\mathrm{cm}^{3} \mathrm{~g}^{-1}\right)$ & Average pore radius / \\
\hline CCRS & 51.11 & 0.050 & 20.2 \\
CCRS-16 min & 6.70 & 0.013 & 19.9 \\
$\mathrm{CCRS} / \mathrm{K}_{2} \mathrm{HPO}_{4}-16 \mathrm{~min}$ & 8.47 & 0.026 & 16.2 \\
\hline
\end{tabular}

CCRS: chrysotile:cement roofing sheets. 
Table 3. Percentage of elements released after $30 \mathrm{~min}$, from both samples (CCRS and CCRS/ $\mathrm{K}_{2} \mathrm{HPO}_{4}$ )

\begin{tabular}{|c|c|c|c|c|}
\hline \multirow{2}{*}{ Element } & \multicolumn{2}{|c|}{ Deionized water } & \multicolumn{2}{|c|}{ Acetic acid solution } \\
\hline & CCRS-16 min & $\mathrm{CCRS} / \mathrm{K}_{2} \mathrm{HPO}_{4}-16 \mathrm{~min}$ & CCRS-16 min & $\mathrm{CCRS} / \mathrm{K}_{2} \mathrm{HPO}_{4}-16 \mathrm{~min}$ \\
\hline $\mathrm{Ca} / \%$ & 13.26 & 13.92 & 26.52 & 17.01 \\
\hline $\mathrm{Mg} / \%$ & 13.95 & 13.04 & 18.61 & 15.22 \\
\hline $\mathrm{K} / \%$ & - & 8.32 & - & 8.68 \\
\hline $\mathrm{P} / \%$ & _- & 4.57 & - & 6.39 \\
\hline
\end{tabular}

CCRS: chrysotile:cement roofing sheets.

slowly, or even by phosphate buffering effect. The samples were monitored for $30 \mathrm{~min}$, but reached equilibrium $\mathrm{pH}$ after $10 \mathrm{~min}$ (Figure 6). In the assays involving deionized water, the $\mathrm{pH}$ increased from 6.19 to 9.16 and 8.93, for the samples CCRS milled for $16 \mathrm{~min}$ and CCRS/ $\mathrm{K}_{2} \mathrm{HPO}_{4}$ milled for $16 \mathrm{~min}$, respectively.



Figure 6. $\mathrm{pH}$ assays in deionized water and aqueous acetic acid solution.

Again, it is clear that the nanometric carbonates, silicates and oxides had strong capacity to increase the $\mathrm{pH}$ of the aqueous solution. With the acetic acid solution, the same behavior was observed for the sample milled in the presence of $\mathrm{K}_{2} \mathrm{HPO}_{4}$, due to the probable partial consumption of the oxides to produce $\mathrm{Mg}$ and $\mathrm{Ca}$ phosphates, which are released slowly.

In the solubilization process, three important species may be formed and are strongly related to the influence on $\mathrm{pH}$. The solubilization of $\mathrm{CaCO}_{3}$ forms $\mathrm{Ca}(\mathrm{OH})_{2}$, a partial soluble base, and also $\mathrm{CO}_{2}$ that can form $\mathrm{HCO}_{3}^{-}$, crucial for capturing $\mathrm{H}^{+}$, increasing the $\mathrm{pH}$ of the solution. Another partial soluble base that may be formed during the process is $\mathrm{Mg}(\mathrm{OH})_{2}$; this base is derived from $\mathrm{MgO}$ formed by mechanochemical activation mainly from chrysotile as evaluated by SAED (data not shown).
Thus, considering these data and examples from the literature related to other layered materials $\mathrm{s}^{27-29,33-35}$ and also to $\mathrm{ACM},{ }^{19,36}$ it is possible to predict that other forms of asbestos with fibrous or layered structures can also be treated by mechanochemical activation in the presence of monohydrogen phosphate (or other phosphates) and release nutrients in water with high nutritional potential.

The literature ${ }^{23}$ also indicates that even in the absence of any use for the materials, mechanochemical activation is cheaper than traditional treatment methods available industrially. This advantage is even stronger when the negative-cost residues obtained from this treatment can be transformed into useful materials, as in the present case.

\section{Conclusions}

The main objective of this study was to reduce or eliminate the hazards of the chrysotile fibers present in CCRS and other objects made from this material, and also to add value to the residues by enabling their use as potential slow-release fertilizers and acid soil conditioners.

The milling of CCRS, a negative-cost waste in the presence of $\mathrm{K}_{2} \mathrm{HPO}_{4}$ mixtures, in a vibration disk mill, eliminated the fiber morphology and produced an almost amorphous mixture of nanometric particles with low aspect ratio. This results in a material that can be used as potential slow release fertilizer and soil conditioner. These characteristics add value to the negative-cost waste while also reducing environmental impacts.

\section{Acknowledgments}

We gratefully acknowledge the Brazilian research agencies CNPq, CAPES and FINEP for financial support of this work. R. B. also thanks CAPES PDSE for the $\mathrm{PhD}$ grant. The authors are also grateful to Loana Mara Baika and Prof Marco Tadeu Grassi for the ICP OES measurements, Waleska da Silva Barbosa for the Herzog mill use and Vinícus Kothe for the BET analysis. 


\section{References}

1. Gualtieri, A. F.; Mineral Fibres: Crystal Chemistry, ChemicalPhysical Properties, Biological Interaction and Toxicity; European Mineralogical Union and Mineralogical Society of Great Britain \& Ireland: London, 2017.

2. Lafaya, R.; Montes-Hernandez, G.; Janots, E.; Chiriac, R.; Findling, N.; Toche, F.; J. Cryst. Growth 2012, 347, 62.

3. Korytkova, E. N.; Maslov, A. V.; Pivovarova, L. N.; Drozdova, I. A.; Gusarov, V. V.; Glass Phys. Chem. 2004, 30, 51.

4. Bales, R. C.; Morgan, J. J.; Environ. Sci. Technol. 1985, 19, 1213.

5. Donaldson, K.; Tran, C. L.; Mutat. Res. 2004, 553, 5.

6. Bernstein, D. M.; Rogers, R. A.; Sepulveda, R.; Kunzendorf, P.; Bellmann, B.; Ernst, H.; Creutzenberg, O.; Phillips, J. I.; Toxicol. Appl. Pharmacol. 2015, 283, 20.

7. Gualtieri, A. F.; Mangano, D.; Gualtieri, M. L.; Ricchi, A.; Foresti, E.; Lesci, G.; Roveri, N.; Mariotti, M.; Pecchini, G.; J. Environ. Manage. 2009, 90, 3540.

8. Spasiano, D.; Pirozzi, F.; J. Environ. Manage. 2017, 204, 82.

9. Turci, F.; Tomatis, M.; Mantegna, S.; Cravotto, G.; Fubini, B.; J. Environ. Monit. 2007, 9, 1064.

10. Valouma, A.; Verganelaki, A.; Tetoros, I.; MaravelakiKalaitzaki, P.; Gidarakos, E.; J. Hazard. Mater. 2017, 336, 93.

11. Kusiorowski, R.; Zaremba, T.; Piotrowski, J.; Gerle, A.; J. Therm. Anal. Calorim. 2013, 113, 179.

12. Nam, S. N.; Jeong, S.; Lim, H.; J. Hazard. Mater. 2014, 265, 151.

13. Anastasiadou, K.; Axiotis, D.; Gidarakos, E.; J. Hazard. Mater. 2010, 179, 926.

14. Belardi, G.; Piga, L.; Thermochim. Acta 2013, 573, 220.

15. Radvanec, M.; Tuček, L.; Derco, J.; Čechovská, K.; Németh, Z.; J. Hazard. Mater. 2013, 252-253, 390.

16. Wypych, F.; Adad, L. B.; Mattoso, N.; Marangon, A. A.; Schreiner, W. H.; J. Colloid Interface Sci. 2005, 283, 107.

17. Leonelli, C.; Veronesi, P.; Boccaccini, D. N.; Rivasi, M. R.; Barbieri, L.; Andreola, F.; Lancellotti, I.; Rabitti, D.; Pellacani, G. C.; J. Hazard. Mater. 2006, 135, 149.

18. Porcu, M.; Orru, R.; Cincotti, A.; Cao, G. C.; Ind. Eng. Chem. Res. 2005, 44, 85.
19. Plescia, P.; Gizzi, D.; Benedetti, S.; Camilucci, L.; Fanizza, C.; De Simone, P.; Paglietti, F.; Waste Manage. 2003, 23, 209.

20. Guo, X.; Xiang, D.; Duan, G.; Mou, P.; Waste Manage. 2010, 30,4 .

21. Suquet, H.; Clays Clay Miner. 1989, 37, 439.

22. Inoue, R.; Kano, J.; Shimme, K.; Saito, F.; Mater. Sci. Forum 2007, 561, 2257.

23. Colangelo, F.; Cioffi, R.; Lavorgna, N.; Verdolotti, L.; De Stefano, L.; J. Hazard. Mater. 2011, 195, 391.

24. Wypych, F.; Schreiner, W. H.; Mattoso, N.; Mosca, D. H.; Marangoni, R.; Bento, C. A. S.; J. Mater. Chem. 2003, 13, 304.

25. Borges, R.; Baika, L. M.; Grassi, M. T.; Wypych, F.; J. Environ. Manage. 2018, 15, 962.

26. Jumate, E.; Manea, D. L.; J. Appl. Eng. Sci. 2011, 1, 79.

27. Borges, R.; Dutra, L. M.; Barison, A.; Wypych, F.; Clay Miner. 2016, 51, 69.

28. Borges, R.; Prevot, V.; Forano, C.; Wypych, F.; Ind. Eng. Chem. Res. 2017, 56, 708.

29. Borges, R.; Brunatto, S. F.; Leitão, A. A.; Carvalho, G. S. G.; Wypych, F.; Clay Miner. 2015, 50, 153.

30. Cullity, B. D.; Stock, S. R.; Elements of X-Ray Diffraction; Prentice-Hall: New York, 2001, p. 167-171.

31. Thommes, M.; Kaneko, K.; Neimark, A. V.; Olivier, J. P.; Rodriguez-Reinoso, F.; Rouquerol, J.; Sing, K. S. W.; Pure Appl. Chem. 2015, 87, 1051.

32. Vdovic, N.; Jurina, I.; Skapin, S. D.; Sondi, I.; Appl. Clay Sci. 2010, 48, 575.

33. Sahnoun, R. D.; Chaari, K.; Bouaziz, J.; Mediterr. J. Chem. 2015, 4, 156.

34. Solihin; Zhang, Q.; Tongamp, W.; Saito, F.; Ind. Eng. Chem. Res. 2010, 49, 2213.

35. Solihin; Zhang, Q.; Tongamp, W.; Saito, F.; Powder Technol. 2011, 212, 354.

36. Milosevic, S.; Tomasevic-Canovic, M.; Dimitrijevic, R.; Petrov, M.; Djuricic, M.; Zivanovic, B.; Am. Ceram. Soc. Bull. 1992, 71,771 .

Submitted: June 6, 2018

Published online: September 17, 2018 